\title{
Pola asuh orang tua dan efikasi diri memengaruhi motivasi dalam menyelesaikan skripsi
}

\author{
Dylla Monica Latief ${ }^{\left.1^{*}\right)}$ \& Kusnarto Kurniawan ${ }^{2}$ \\ Universitas Negeri Semarang ${ }^{12}$ \\ *) Alamat korespondensi: Jl. Raya Sekaran, Kota Semarang, 50229, Indonesia; E-mail: dylla.monica@gmail.com, \\ kusnarto@mail.unnes.ac.id
}

Article History: Received: 19/06/2021; Revised: 23/06/2021; Accepted: 23/06/2021; Published: $30 / 06 / 2021$

How to cite: Latief, D.M. \& Kurniawan, K. (2021). Pola asuh orang tua dan efikasi diri memengaruhi motivasi dalam menyelesaikan skripsi. Bimbingan dan Konseling, 5(1), pp. 97-108. DOI: 10.26539/teraputik.51657

\section{(c) (i) This is an open} distributed under the Creative Commons 4.0 Attribution License, which permits unrestricted use, distribution, and reproduction in any medium, provided the original work is properly cited. ( ) 2021, Latief, D.M. \& Kurniawan, K.(s).

\begin{abstract}
Abstrak: Penelitian ini bertujuan untuk mengetahui pengaruh pola asuh orang tua dan efikasi diri terhadap motivasi dalam menyelesaikan skripsi. Penelitian ini dilakukan pada 5.600 mahasiswa Universitas Negeri Semarang tahun angkatan 2016. Penentuan sampel menggunakan proportional insidental sampling, menggunakan rumus slovin dengan jumlah sampel sebesar 373 mahasiswa. Pengumpulan data menggunakan tiga skala yaitu pola asuh, efikasi diri dan skala motivasi akademik yang telah diuji validitas dan reliabilitasnya. Teknik analisis data menggunakan analisis deskriptif dan analisis inferensial. Hasil penelitian mengungkapkan bahwa terdapat pengaruh yang positif dan signifikan pola asuh orang tua dan efikasi diri terhadap motivasi dalam menyelesaikan skripsi dengan kontribusi nilai koefisien determinasi (R Square) sebesar 56,9\%, sedangkan sisanya $43,1 \%$ dipengaruhi oleh variabel lain di luar variabel yang diteliti. Saran yang harus dipahami yaitu mahasiswa perlu menyadari pentingnya keseriusan dan ketekunan dalam menyelesaikan skripsi, karena tanpa adanya keinginan dari dalam diri, motivasi tidak akan terwujud.
\end{abstract}

Kata Kunci: Pola Asuh, Efikasi Diri, Motivasi

Abstract: This research aims to know the effect of parenting and self-efficacy on motivation in completing the minithesis. This research was conducted on 5,600 Semarang State University students in 2016. The sample determination used proportional incidental sampling, using the Slovin formula with a total sample of 373 students. Data collection uses three scales, namely parenting, self-efficacy and academic motivation scale which have been tested for validity and reliability. The data analysis technique used descriptive analysis and inferential analysis. The results of the research revealed that there was a positive and significant effect of parenting and self-efficacy on motivation in completing the thesis with the contribution of the coefficient of determination ( $R$ Square) of $56.9 \%$, while the remaining $43.1 \%$ was influenced by other variables outside the variable. researched. Suggestions that must be understood are that students need to realize the importance of seriousness and perseverance in completing the minithesis, because without the desire from within, motivation will not materialize.

Keywords: Parenting Style, Self-Efficacy, Motivation

\section{Pendahuluan}

Skripsi merupakan karya ilmiah atau penelitian dalam bidang studi terhadap suatu masalah tertentu yang ditulis oleh mahasiswa program sarjana (S1) pada akhir studinya. Penelitian ini menunjukkan kemampuan mahasiswa menyusun pikiran secara sistematis, logis, kritis, terpadu dan mengikuti kaidah kaidah ilmiah. Skripsi merupakan karya ilmiah penelitian yang memiliki dasar hukum kuat sebagai karya ilmiah sehingga mampu menjadi dasar dan referensi bagi penelitian lainnya, skripsi dalam penulisannya harus selaras dengan sumber data dan referensi yang ada, sehingga hipotesis dan analisis yang dilakukan relevan dengan bidang keahlian atau bidang studi yang diambil (Maulana 2012:6-7), sejalan dengan hal tersebut Universitas Negeri Semarang juga memiliki ketentuan yang telah diatur didalam buku panduan akademik yang menyatakan bahwa mahasiswa yang telah menyelesaikan 90 sks diwajibkan menyusun/menulis skripsi (Anonim, 2012:49). Terkait dengan kebijakan tersebut Maulana (2012) menyatakan bahwa kebijakan ini menjadi dorongan untuk menghasilkan mahasiswa yang 
berkualitas dari segi intelektual sebagai ajang untuk meningkatkan kualitas belajar seorang mahasiswa.

Hasil survei awal melalui penyebaran skala pada hari Sabtu, 8 Februari 2020 dengan empat puluh enam mahasiswa tingkat akhir Universitas Negeri Semarang tahun angkatan 2016 sebesar $65,2 \%$ mahasiswa setuju bahwa skripsi merupakan suatu hal yang sulit, selain itu dalam penyusunan skripsi mahasiswa selalu merasa tertekan, takut, cemas, bosan, terpaksa, sehingga malas untuk mengerjakan, menyusun skripsi membuat mahasiswa terlihat bodoh karena mahasiswa menganggap teknis penyusunan skripsi rumit, dengan prosedur yang panjang dan banyak persyaratan, selain itu minimnya minat baca serta sulitnya menemukan referensi jurnal atau buku menjadi faktor penghambat mahasiswa dalam menyelesaikan skripsi. Mahasiswa yang takut menghadapi skripsi cenderung memiliki rasa malas. Rasa malas terhadap tugas akademik menandakan lemahnya motivasi mahasiswa. Tanpa motivasi, mahasiswa tidak akan bersemangat dalam menyelesaikan tugas akademiknya. Oleh karena itu, terbentuklah pola pikir yang mendorong mereka untuk berat dalam menyelesaikan skripsi.

Menurut Zulkarnain (2010:6) faktor utama skripsi dianggap sulit, tidak mungkin cepat, butuh waktu panjang, dan pikiran-pikiran negatif lainnya disebabkan oleh faktor internal yaitu pemikiran mahasiswa. Selain itu tidak ada perencanaan penyusunan skripsi yang matang sejak awal kuliah atau sebelum menyusun skripsi seperti perencanaan waktu yang baik, perencanaan SDM, dan jaringan yang luas serta penguasaan pengetahuan yang mendalam, akibatnya mahasiswa seperti berjalan tanpa arah dan tujuan kemudian melakukan penundaan dan menyimpulkan skripsi adalah hal yang sulit. Kenyataannya menyusun skripsi itu mudah, seperti menyusun karangan ilmiah lainnya. Perbedaannya adalah skripsi menggunakan metode ilmiah yang terdiri dari langkah-langkah untuk mengorganisasi dan mengatur gagasan konseptual dan prosedural yang disepakati oleh masing-masing perguruan tinggi. Sehingga dengan mempelajari cara dan mengikuti arahan yang diberikan oleh dosen pembimbing setiap mahasiswa dapat menyelesaikannya dengan mudah. Penulisan skripsi merupakan kombinasi antara kemauan, kerja keras, dan hubungan yang baik bukan ditentukan oleh kepintaran atau tinggi atau rendahnya IPK mahasiswa (Arifah, 2016:3-4).

Selain faktor dari dalam individu, faktor dari luar yakni pola asuh dalam keluarga memberikan pengaruh sangat besar untuk pembentukkan dan perkembangan kepribadian individu. Hasil wawancara pada hari Senin, 17 Februari 2020 dengan enam mahasiswa tingkat akhir UNNES tahun angkatan 2016 menunjukan bahwa pola asuh menjadi salah satu faktor keluarga yang mempengaruhi motivasi individu. Hal ini didukung dengan tanggapan mahasiswa yang menyatakan bahwa pola asuh yang terbuka dengan perhatian yang ditunjukan dalam bentuk pertanyaan seputar perkembangan skripsi, mempengaruhi keinginan mereka untuk segera menyelesaikannya. Sehingga dalam hal ini pola asuh dari orang tua dianggap selalu menjadi patokan anak dalam bersikap dan berperilaku.

Dena Laksmi dkk (2018) menyatakan bahwa anak dapat dipastikan mengikuti perilaku orang tuanya, dan lebih dari itu anak juga akan mengikuti pandangan, pola pikir, dan nilai-nilai yang diantut oleh orang tua. Hal inilah yang menjadi dasar tanggung jawab orang tua di dalam keluarga bukan hanya memenuhi kebutuhan fisik dan materi untuk anaknya, akan tetapi juga kebutuhan psikis pada anak. Seperti bagaimana orang tua mengontrol, membimbing, dan mendampingi anak-anaknya, memberikan sentuhan, kasih sayang, dan perhatian kepada anak dapat membuat anak merasa mendapatkan perhatian yang lebih dan merasakan kenyamanan jika berada dalam pengasuhannya. Kondisi tersebut akan menumbuhkan motivasi anak untuk belajar, sebaliknya orang tua yang acuh terhadap anak akan menimbulkan rendahnya motivasi belajar pada anak.

Selain pola asuh orang tua masih ada hal yang perlu diperhatikan guna menumbuhkan motivasi dalam menyelesaikan skripsi mahasiswa yaitu efikasi diri. Efikasi diri sangat penting dalam meningkatkan motivasi seseorang (Fitriyanti \& Bilqis, 2020b; Fitriyanti \& Bilqis, 2020a). Cervone, Daniel dan Pervin (2012:231) menyatakan bahwa manusia dengan efikasi diri yang lebih tinggi cenderung memilih untuk berupaya mengerjakan tugas yang sulit, gigih dalam upaya mereka, tetap tenang dan tidak cemas ketika menghadapi tugas, dan mengelola pikiran mereka dalam pola analitis. Efikasi mempengaruhi pemikiran individu pola dan reaksi emosi, sehingga orang dengan efikasi diri yang rendah akan percaya bahwa segala sesuatu akan jauh lebih sulit 
dari pada yang sebenarnya. Sejauh ini lima dari enam mahasiswa memiliki keyakinan untuk dapat menyelesaikan skripsi mereka. Menurut mereka keyakinan tersebut muncul karena motivasimotivasi lain, seperti keinginan untuk segera mendapatkan pekerjaan, serta dorongan untuk berkompetisi dengan teman-teman mereka.

Melihat literatur dan fenomena yang terjadi, peneliti tertarik untuk melakukan penelitian mengenai motivasi dalam menyelesaikan skripsi terutama untuk mencari jawaban tentang "Pengaruh Pola Asuh Orang Tua Dan Efikasi Diri Terhadap Motivasi Dalam Menyelesaikan Skripsi Pada Mahasiswa Tingkat Akhir Universitas Negeri Semarang".

\section{Metode}

Penelitian ini menggunakan jenis penelitian kuantitatif. Populasi dalam penelitian ini adalah mahasiswa tingkat akhir Universitas Negeri Semarang tahun angkatan 2016 yang berjumlah 5.600 mahasiswa. Sampel penelitian ini menggunakan rumus slovin dengan standar eror 5\% sejumlah 373 mahasiswa. Pengambilan sampel pada penelitian ini menggunakan teknik insidental sampling atau sampel insidental yakni teknik penentuan sampling berdasarkan kebetulan, yaitu siapa saja yang secara kebetulan bertemu dengan peneliti dapat digunakan sebagai sampel, bila dipandang orang yang kebetulan ditemui itu cocok sebagai sumber data (Sugiyono, 2017:124). Pengumpulan data menggunakan assesmen non tes berupa tiga skala yaitu pola asuh, efikasi diri dan skala motivasi akademik yang telah diuji validitas dan reliabilitasnya, dengan menggunakan model skala likert empat poin. Teknik analisis data menggunakan analisis statistik deskiptif dan analisis regresi linier berganda.

\section{Hasil dan Diskusi}

Data penelitian yang diperoleh berasal dari pengisian kuesioner responden yang kemudian dianalisis menggunakan analisis statistik deskriptif.

\section{Hasil}

Analisis Deskriptif Variabel Motivasi Dalam Menyelesaikan Skripsi

Hasil analisis statistik deskiptif menunjukkan motivasi dalam menyelesikan skripsi pada mahasiswa tingkat akhir Universitas Negeri Semarang tahun angkatan 2016 dalam kategori sedang. Berikut adalah hasil analisis statistik deskriptif variabel motivasi dalam menyelesikan skripsi yang menunjukkan kategori sedang.

Analisis statistik deskriptif pada penelitian ini menggunakan SPSS 21. Variabel motivasi dalam menyelesaikan skripsi diukur dengan menggunakan delapan indikator yaitu, Pengaturan Eksternal, Introyeksi, Identifikasi, Motivasi untuk Mengetahui, Motivasi Berprestasi, Motivasi untuk Penyaluran Diri, Mengalami Stimulasi, Memiliki Perasaan Tidak Mampu yang dijabarkan ke dalam 31 pernyataan. Hasil dari statistik deskriptif dapat dilihat pada tabel 1:

Tabel 1. Deskriptif Statistik Variabel Motivasi Dalam Menyelesaikan Skripsi

\begin{tabular}{|c|c|c|c|c|c|}
\hline & \multicolumn{4}{|c|}{ Descriptive Statistics } & \multirow[b]{2}{*}{ Std. Deviation } \\
\hline & $\mathrm{N}$ & Minimum & Maximum & Mean & \\
\hline $\begin{array}{l}\text { Motivasi dalam } \\
\text { menyelesaikan } \\
\text { skripsi }\end{array}$ & 373 & 46 & 118 & 91.31 & 11.340 \\
\hline $\begin{array}{c}\text { Valid N } \\
\text { (Listwise) }\end{array}$ & 373 & & & & \\
\hline
\end{tabular}

Berdasarkan tabel 1 dapat disimpulkan bahwa dari 31 item pertanyaan pada variabel motivasi dalam menyelesaikan skripsi dengan nilai tertinggi 118 dan nilai terendah 46 dengan standar deviasi sebesar 11,34. Rata-rata nilai untuk variabel motivasi dalam menyelesaikan 
skripsi adalah 91.31 yang termasuk dalam kategori sedang, kategori tersebut mengacu pada tabel 2.

Tabel 2. Analisis Deskriptif Distribusi Frekuesi Variabel Motivasi Dalam Menyelesaikan Skripsi

\begin{tabular}{ccccc}
\hline No. & Interval & Jumlah & Presentase & Kiteria \\
\hline 1 & $103-124$ & 61 & $16,35 \%$ & Tinggi \\
\hline 2 & $79-102$ & 264 & $70,77 \%$ & Sedang \\
\hline 3 & $55-78$ & 47 & $12,60 \%$ & Rendah \\
\hline 4 & $31-54$ & 1 & $0,26 \%$ & Sangat \\
& & & & Rendah
\end{tabular}

Sumber: Diolah dari data penelitian, 2020

Pada tabel 2 dapat dilihat bahwa dari 373 responden mahasiswa S1 Universitas Negeri Semarang tahun angkatan 2016 yang memiliki motivasi dalam menyelesaikan skripsi yang tinggi sejumlah 61 mahasiswa atau 16,35\%, motivasi dalam menyelesaikan skripsi dalam kategori sedang sejumlah 264 mahasiswa atau 70,77\% persentase ini merupakan paling tinggi diantara kategori yang lainnya, motivasi dalam menyelesaikan skripsi dalam kategori rendah sebanyak 47 mahasiswa atau $12,60 \%$, kemudian yang termasuk ke dalam motivasi dalam menyelesaikan skripsi dalam kategori sangat rendah sejumlah 1 mahasiswa atau 0,26\%. Berikut hasil rekapitulasi hasil jawaban responden untuk setiap pertanyaan pada variabel motivasi dalam menyelesaikan skripsi yang tersajikan pada tabel 3 .

Tabel 3. Rata - Rata Deskriptif Per Indikator Variabel Motivasi Dalam Menyelesaikan Skripsi

\begin{tabular}{cccc}
\hline No & Indikator & Rata-rata Skor & Kriteria \\
\hline 1 & Pengaturan Eksternal & 5,9 & Rendah \\
\hline 2 & Introyeksi & 2,6 & Rendah \\
\hline 3 & Identifikasi & 11,6 & Sedang \\
\hline 4 & Motivasi Untuk Mengetahui & 24 & Sedang \\
\hline 5 & Motivasi Berprestasi & 25,9 & Sedang \\
\hline 6 & Motivasi Untuk Penyaluran Diri & 9 & Sedang \\
\hline 7 & Mengalami Stimulasi & 8 & Rendah \\
\hline 8 & \multirow{2}{*}{ Memiliki Perasaan Tidak Mampu } & 3,9 & Sangat \\
& & & Rendah
\end{tabular}

Sumber: Diolah dari data penelitian, 2020

Berikut adalah tabel 4 yang merupakan ringkasan analisis rata-rata per indikator berdasarkan tabel jawaban responden yang ada pada tabel 3 .

Tabel 4. Rata - rata Deskriptif Per Fakultas Variabel Motivasi Dalam Menyelesaikan Skripsi

\begin{tabular}{cccc}
\hline No & Fakultas & Rata-rata Skor & Kriteria \\
\hline 1 & Fakultas Ilmu Pendidikan & 91,15 & Sedang \\
\hline 2 & Fakultas Bahasa dan Seni & 88 & Sedang \\
\hline 3 & Fakultas IImu Sosial & 94,11 & Sedang \\
\hline 4 & Fakultas Matematika dan IPA & 93,54 & Sedang \\
\hline 5 & Fakultas Teknik & 92,20 & Sedang \\
\hline 6 & Fakultas Ilmu Keolahragaan & 90,95 & Sedang \\
\hline 7 & Fakultas Ekonomi & 91,48 & Sedang \\
\hline 8 & Fakultas Hukum & 90,68 & Sedang
\end{tabular}

Sumber: Diolah dari data penelitian, 2020 


\section{Analisis Statistik Deskriptif Variabel Pola Asuh Orang Tua}

Hasil analisis statistik deskiptif menunjukkan pola asuh orang tua pada mahasiswa tingkat akhir Universitas Negeri Semarang tahun angkatan 2016 dalam kategori sedang. Berikut adalah hasil analisis statistik deskriptif variabel pola asuh orang tua yang menunjukkan kategori baik.

Pada analisis statistik deskriptif variabel pola asuh orang tua menggunakan dua indikator yaitu: dorongan dan tuntutan yang terdiri dari 22 pernyataan. Hasil analisis deskriptif dapat dilihat pada tabel 5.

Tabel 5. Deskriptif Statistik Variabel Pola Asuh Orang Tua

\begin{tabular}{cccccc}
\hline \multicolumn{6}{c}{ Descriptive Statistics } \\
\hline & $\mathrm{N}$ & Minimum & Maximum & Mean & Std. Deviation \\
\hline Valid N (listwise) & 373 & 28 & 84 & 65.95 & 9.332 \\
\hline
\end{tabular}

Sumber: Diolah dari data penelitian, 2020

Berdasarkan hasil data penelitian yang telah dijabarkan ke dalam 22 pernyataan diketahui bahwa nilai terendah variabel pola asuh orang tua sebesar 28 , dan nilai tertinggi 84 . Standar deviasi yang dihasilkan sebesar 9,33 dengan rata-rata 65,95. Angka rata-rata pada variabel pola asuh orang tua termasuk dalam kategori baik. Kategori ini mengacu pada tabel 6 :

Tabel 6. Analisis Deskriptif Distribusi Frekuesi Variabel Pola Asuh Orang Tua

\begin{tabular}{ccccc}
\hline No. & Interval & Jumlah & Presentase & Kiteria \\
\hline 1 & $73-88$ & 107 & $28,68 \%$ & Sangat Baik \\
2 & $56-72$ & 220 & $58,98 \%$ & Baik \\
3 & $39-55$ & 42 & $11,26 \%$ & Kurang Baik \\
4 & $22-38$ & 4 & $1,07 \%$ & Tidak Baik \\
\hline
\end{tabular}

Sumber: Diolah dari data penelitian, 2020

Berdasarkan tabel 6 dapat disimpulkan bahwa dari 373 responden mahasiswa S1 Universitas Negeri Semarang tahun angkatan 2016 yang medapatkan pola asuh orang tua dengan sangat baik sejumlah 107 mahasiswa atau 28,68\%, sedangkan yang mendapatkan pola asuh orang tua dengan kategori baik sejumlah 220 mahasiswa atau 58,98\% persentase ini merupakan paling tinggi diantara kategori yang lainnya, kemudian yang mendapatkan pola asuh orang tua dengan kategori kurang baik sebanyak 42 mahasiswa atau 11,26\%, dan yang termasuk mendapatkan pola asuh orang tua dengan kategori tidak baik sejumlah 4 mahasiswa atau sejumlah 1,07\%. Berikut hasil rekapitulasi hasil jawaban responden untuk setiap pernyataan pada variabel pola asuh orang tua yang tersajikan pada tabel 7 .

Tabel 7. Rata - rata Deskriptif Per Indikator Variabel Pola Asuh Orang Tua

\begin{tabular}{cccc}
\hline No & Indikator & Rata-rata Skor & Kriteria \\
\hline 1 & Dorongan & 46,2 & Baik \\
\hline 2 & Tuntutan & 18,4 & Kurang Baik \\
\hline
\end{tabular}

Sumber: Diolah dari data penelitian, 2020

Berikut adalah tabel 8 yang merupakan ringkasan analisis rata-rata per indikator berdasarkan tabel jawaban responden yang ada pada tabel 7 . 
Tabel 8. Rata - rata Deskriptif Per Fakultas Variabel Pola Asuh Orang Tua

\begin{tabular}{cccc}
\hline No & Fakultas & Rata-rata Skor & Kriteria \\
\hline 1 & Fakultas IImu Pendidikan & 67 & Baik \\
\hline 2 & Fakultas Bahasa dan Seni & 63,65 & Baik \\
\hline 3 & Fakultas IImu Sosial & 65,88 & Baik \\
\hline 4 & Fakultas Matematika dan IPA & 66,52 & Baik \\
\hline 5 & Fakultas Teknik & 67,17 & Baik \\
\hline 6 & Fakultas Ilmu Keolahragaan & 65,18 & Baik \\
\hline 7 & Fakultas Ekonomi & 67,19 & Baik \\
\hline 8 & Fakultas Hukum & 64,47 & Baik \\
\hline
\end{tabular}

Sumber: Diolah dari data penelitian, 2020

\section{Analisis Statistik Deskriptif Variabel Efikasi Diri}

Analisis statistik deskriptif Variabel efikasi diri diukur dengan menggunakan tiga indikator yaitu: tingkat kesulitan tugas (magnitude), luas bidang tugas (generality), dan kekuatan keyakinan (strength). Indikator tersebut dijabarkan ke dalam 27 pernyataan. Hasil dari statistik deskriptif dapat dilihat pada tabel 9:

Tabel 9. Deskriptif Statistik Variabel Efikasi Diri

\begin{tabular}{cccccc}
\hline \multicolumn{5}{c}{ Descriptive Statistics } \\
\hline Efikasi diri & $\mathrm{N}$ & Minimum & Maximum & Mean & Std. Deviation \\
\hline Valid N (listwise) & 373 & 38 & 107 & 82.67 & 11.158 \\
\hline
\end{tabular}

Sumber: Diolah dari data penelitian, 2020

Berdasarkan hasil data penelitian pada tabel 9 diketahui bahwa nilai terendah variabel efikasi diri sebesar 38, dan nilai tertinggi 107. Standar deviasi yang dihasilkan sebesar 11,158 dengan rata-rata 82,67. Angka rata-rata pada variabel efikasi diri termasuk dalam kategori sedang. Kategori ini mengacu pada tabel 10.

Tabel 10. Analisis Deskriptif Distribusi Frekuesi Variabel Efikasi Diri

\begin{tabular}{ccccc}
\hline No. & Interval & Jumlah & Presentase & Kiteria \\
\hline 1 & $90-108$ & 111 & $29,75 \%$ & Tinggi \\
2 & $69-89$ & 225 & $60,32 \%$ & Sedang \\
3 & $48-68$ & 36 & $9,65 \%$ & Rendah \\
4 & $27-47$ & 1 & $0,26 \%$ & Sangat Rendah \\
\hline
\end{tabular}

Sumber: Diolah dari data penelitian, 2020

Pada tabel 10 dapat dilihat bahwa dari 373 responden mahasiswa S1 Universitas Negeri Semarang tahun angkatan 2016 yang memiliki efikasi diri yang tinggi sejumlah 111 mahasiswa atau $29,75 \%$, efikasi diri kategori sedang sejumlah 225 mahasiswa atau 60,32\% angka ini merupakan persentase paling tinggi diantara kategori yang lainnya, kemudian yang termasuk ke dalam efikasi diri kategori rendah sejumlah 36 mahasiswa atau 9,65\% dan kategori efikasi diri paling rendah yakni sejumlah 1 mahasiswa atau 0,26\%. Berikut hasil rekapitulasi hasil jawaban responden untuk setiap pertanyaan pada variabel efikasi diri yang tersajikan pada tabel 11:

Tabel 11. Rata - rata Deskriptif Per Indikator Variabel Efikasi Diri

\begin{tabular}{cccc} 
No & Indikator & Rata-rata Skor & Kriteria \\
\hline 1 & Tingkat Kesulitan Tugas & 28,2 & Sedang \\
2 & Luas Bidang Tugas & 36,8 & Sedang
\end{tabular}


Sumber: Diolah dari data penelitian, 2020

16

Sedang

Berikut adalah tabel 12 yang merupakan ringkasan analisis rata-rata per indikator berdasarkan tabel jawaban responden yang ada pada tabel 11:

Tabel 12. Rata - rata Dekriptif Per Fakultas Variabel Efikasi Diri

\begin{tabular}{cccc}
\hline No & Fakultas & Rata-rata Skor & Kriteria \\
\hline 1 & Fakultas Ilmu Pendidikan & 81,95 & Sedang \\
2 & Fakultas Bahasa dan Seni & 79,80 & Sedang \\
3 & Fakultas IImu Sosial & 85,54 & Sedang \\
4 & Fakultas Matematika dan IPA & 86,04 & Sedang \\
5 & Fakultas Teknik & 84,08 & Sedang \\
6 & Fakultas Ilmu Keolahragaan & 83,13 & Sedang \\
7 & Fakultas Ekonomi & 82,17 & Sedang \\
8 & Fakultas Hukum & 78,05 & Sedang \\
\hline
\end{tabular}

Sumber: Diolah dari data penelitian, 2020

\section{Analisis Regresi Linier Berganda}

Analisis uji regresi linier berganda digunakan untuk mengetahui arah hubungan antara dua atau lebih variabel independen dengan variabel dependen. Sebelum dilakukan uji regresi linier berganda, terlebih dahulu dilakukan uji asumsi klasik. Hasil uji asumsi klasik pada uji normalitas menggunakan uji statistik Kolmogorov - Smirov diperoleh nilai probabilitas 0,483 > 0,05 ini berarti data pada penelitian ini dikatakan berdistribusi normal. Pada uji linearitas menggunakan uji lagrange multiplier dengan motivasi dalam menyelesaikan skripsi sebagai variabel dependen menunjukan nilai $c^{2}$ hitung $0,373<c^{2}$ tabel sebesar 415,852, maka dapat disimpulkan bahwa model peneltian ini merupakan persamaan yang linear.

Uji asumsi klasik selanjutnya yakni uji multikolinearitas dimana masing-masing variabel bebas mempunyai nilai tolerance lebih dari 0,10 dan nilai VIF kurang dari 0,10 , sehingga dapat disimpulkan bahwa tidak terjadi multikolinearitas. Selajutnya uji heteroskedastisitas melalui uji glejser diperoleh nilai signifikansi untuk semua variabel bebas sebesar $>0,05$ sehingga dapat disimpulkan bahwa tidak terjadi heteroskedastisitas. Berikut ini adalah uji regresi linier berganda:

Tabel 13. Hasil Analisis Regresi Linier Berganda

Coefficients $^{\mathrm{a}}$

\begin{tabular}{|c|c|c|c|c|c|}
\hline \multirow{2}{*}{ Model } & \multicolumn{2}{|c|}{ Unstandardized Coefficients } & Standardized Coefficients & \multirow{2}{*}{$\mathrm{t}$} & Sig. \\
\cline { 2 - 6 } & $\mathrm{B}$ & Std. Error & Beta & & 6.572 \\
\hline (Constant) & 42.275 & 6.433 & & .000 \\
POLA ASUH & .116 & .048 & .091 & 2.405 & .017 \\
ORANG TUA & .810 & .043 & .710 & 18.743 & .000 \\
\hline
\end{tabular}

a. Dependent Variable: MOTIVASI DALAM MENYELESAIKAN SKRIPSI

Sumber: Diolah dari data penelitian, 2020

Tabel 13 menunjukkan bahwa nilai konstanta sebesar 42,275 dan nilai koefisien regresi masing-masing variabel dapat dilihat pada kolom B. Variabel Pola asuh orang tua memiliki koefisien regresi sebesar 0,116, dan variabel Efikasi Diri memiliki koefisien 0,810, sehingga diperoleh persamaan analisis regresi linier berganda sebagai berikut.

$$
Y=42,275+0,116 X 1+0,810 X 2
$$




\section{Pengaruh Pola Asuh Orang Tua Terhadap Motivasi Dalam Menyelesaikan Skripsi}

Hasil penelitian menunjukkan bahwa pola asuh orang tua memiliki pengaruh terhadap motivasi dalam menyelesaikan skripsi, hal ini ditunjukkan dengan nilai t hitung sebesar 2,405 dengan signifikansi $0,017<0,05$. Nilai koefisien regresi pola asuh orang tua menunjukkan nilai arah positif dengan motivasi dalam menyelesaikan skripsi yang berarti bahwa pola asuh orang tua berpengaruh secara signifikan dan positif terhadap motivasi dalam menyelesaikan skripsi pada mahasiswa tingkat akhir Universitas Negeri Semarang tahun angkatan 2016, sehingga hipotesis pertama pada penelitian ini diterima.

Hasil penelitian ini sejalan dengan hasil penelitian yang dilakukan oleh Dinniar (2017) dan Mustolikh dan S.F Salihati (2014) menyatakan bahwa hasil analisis regresi dalam penelitiannya menunjukkan adanya pengaruh yang signifikan antara variabel pola asuh orang tua terhadap motivasi akademik. Pola asuh orang tua menjadi faktor penting yang mampu mengarahkan dan memotivasi individu. Didalam teori yang dicetuskan oleh Abraham Maslow (1970) yang disebut hierarki kebutuhan telah ditunjukan bahwa orang tua berperan penting untuk memenuhi tahapan kebutuhan dasar anak sebagai manusia yakni dimulai dari kebutuhan fisiologis, rasa aman, cinta dan kasih, dan aktualisasi diri. Hal ini menunjukan bahwa tanggung jawab yang dipikul orang tua memerlukan pemikiran dan perhatian yang besar dan segala hal yang ditanamkan orang tua dalam pola pengasuhannya, hal tersebut meninggalkan dasar yang paling dalam bagi pendidikan anak.

Merujuk pada pembahasan diatas maka dapat disimpulkan bahwa masing-masing pola asuh orang tua yang ada akan memberikan pengaruh yang berbeda terhadap pembentukan kepribadian dan perilaku anak, sebab orang tua merupakan lingkungan terdekat yang selalu mengitari anak sekaligus menjadi figur dan idola mereka, sehingga jika mahasiswa mendapatkan perlakuan (pola asuh) yang baik dari orang tua maka semakin baik pula motivasinya dalam menyelesaikan skripsi karena sikap mahasiswa terhadap akademik akan dipengaruhi oleh sikap orang tua mereka.

\section{Pengaruh Efikasi Diri Terhadap Motivasi Dalam Menyelesaikan Skripsi}

Pada penelitian ini menunjukkan hasil bahwa efikasi diri memiliki pengaruh terhadap motivasi dalam menyelesaikan skripsi, hal ini ditunjukkan dengan nilai t hitungnya 18,743 dengan signifikansi $0,000<0,05$. Nilai koefisien regresi efikasi diri menunjukkan nilai arah positif dengan motivasi dalam menyelesaikan skripsi yang dapat diartikan bahwa efikasi diri berpengaruh secara signifikan dan positif terhadap motivasi dalam menyelesaikan skripsi pada mahasiswa akhir Universitas Negeri Semarang tahun angkatan 2016, sehingga hipotesis kedua pada penelitian ini diterima.

Hasil ini sejalan dengan hasil penelitian yang dilakukan oleh Kusumawati (2018) menyatakan bahwa efikasi diri memberikan pengaruh terhadap motivasi berprestasi siswa dengan koefisien determinasi sebesar $49,2 \%$. Selain itu penelitian yang dilakukan oleh Amir (2016) juga menyatakan bahwa ada pengaruh signifikan dari aspek efikasi diri terhadap motivasi mahasiswa dengan koefisien determinasi sebesar 33,83\%. Hal ini menunjukkan bahwa efikasi diri yang dimiliki mahasiswa selalu berhubungan sangat erat dan akan sangat mempengaruhi motivasi yang dimilikinya. Sesuai dengan teori Bandura dalam Pajares (1996) mengenai efikasi diri, bahwa efikasi diri ini memiliki peran dalam mempengaruhi perilaku individu melalui beberapa cara yakni mempengaruhi pilihan yang diambil individu dan tindakan yang mereka kejar.

Berdasarkan pembahasan diatas dapat disimpulkan bahwa dengan efikasi diri yang dimiliki apabila mahasiswa memiliki efikasi diri yang tinggi, maka semakin tinggi pula motivasinya dalam menyelesaikan skripsi, karena mahasiswa yang memiliki efikasi diri yang tinggi dapat menumbuhkan dan menjaga keinginan serta semangatnya dalam menyelesaikan skripsi. 


\section{Skripsi \\ Pengaruh Pola Asuh Orang Tua Dan Efikasi Diri Terhadap Motivasi Dalam Menyelesaikan}

Berikut ini adalah hasil Uji F:

Tabel 14. Uji F

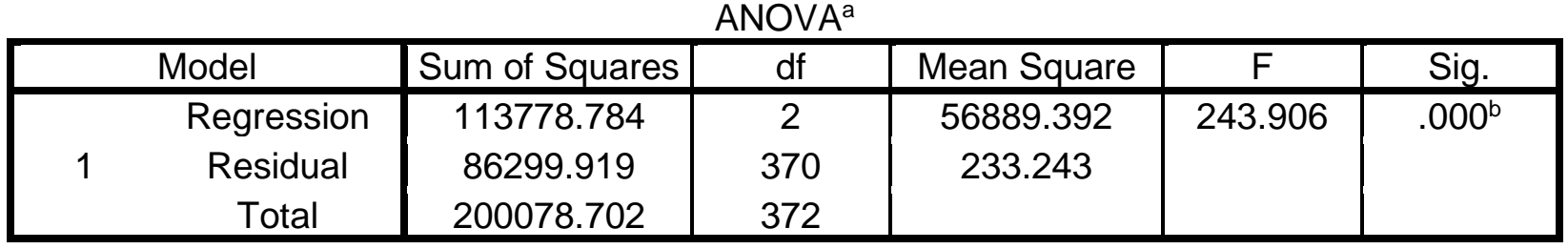

a. Dependent Variable: MOTIVASI DALAM MENYELESAIKAN SKRIPSI

b. Predictors: (Constant), EFIKASI DIRI, POLA ASUH ORANG TUA

Sumber: Diolah dari data penelitian, 2020

Berdasarkan Tabel 14 penelitian yang telah dilakukan pada mahasiswa tingkat akhir Universitas Negeri Semarang tahun angkatan 2016 menunjukkan hasil bahwa pola asuh orang tua dan efikasi diri memiliki pengaruh secara simultan (bersama-sama) terhadap motivasi dalam menyelesaikan skripsi, hal ini ditunjukkan dengan nilai $F$ hitungnya 243,906 dengan signifikansi $0,000<0,05$. Nilai koefisien determinasi bernilai positif menunjukkan pengaruh pola asuh orang tua dan efikasi diri terhadap motivasi dalam menyelesaikan skripsi adalah positif. Hal tersebut berarti H3 yang berbunyi pola asuh orang tua dan efikasi diri berpengaruh positif terhadap motivasi dalam menyelesaikan skripsi dinyatakan diterima.

Hasil uji analisis koefisien determinasi (R Square) menunjukan angka sebesar 0,569 atau sama dengan $56,9 \%$. Sehingga dapat disimpulkan bahwa variabel Pola asuh dan Efikasi diri berpengaruh secara simultan terhadap variabel motivasi dalam menyelesaikan skripsi sebesar $56,9 \%$. Sedangkan sisanya $43,1 \%$ dipengaruhi oleh variabel lain di luar persamaan regresi ini atau di luar variabel yang diteliti. Oleh karena itu, dapat disimpulkan bahwa motivasi dalam menyelesaikan skripsi tidak akan diperoleh secara maksimal apabila pola asuh dan efikasi pada diri mahasiswa tidak maksimal.

\section{Diskusi}

Hasil penelitian menunjukkan bahwa pola asuh orang tua memiliki pengaruh terhadap motivasi dalam menyelesaikan skripsi, hal ini ditunjukkan dengan nilai t hitung sebesar 2,405 dengan signifikansi $0,017<0,05$. Nilai koefisien regresi pola asuh orang tua menunjukkan nilai arah positif dengan motivasi dalam menyelesaikan skripsi yang berarti bahwa pola asuh orang tua berpengaruh secara signifikan dan positif terhadap motivasi dalam menyelesaikan skripsi pada mahasiswa tingkat akhir Universitas Negeri Semarang tahun angkatan 2016, sehingga hipotesis pertama pada penelitian ini diterima.

Hasil penelitian ini sejalan dengan hasil penelitian yang dilakukan oleh Dinniar (2017) dan Mustolikh dan S.F Salihati (2014) menyatakan bahwa hasil analisis regresi dalam penelitiannya menunjukkan adanya pengaruh yang signifikan antara variabel pola asuh orang tua terhadap motivasi akademik. Pola asuh orang tua menjadi faktor penting yang mampu mengarahkan dan memotivasi individu.

Hal tersebut juga didukung dengan analisis statistik deskriptif pada variabel pola asuh orang tua yang termasuk dalam kategori baik. Pola asuh orang tua yang baik akan membentuk motivasi yang baik pula. Dena, Laksmi dkk (2018) menyatakan bahwa pola asuh dari orang tua selalu menjadi patokan anak dalam bersikap dan berperilaku. Individu yang mendapatkan tingkat pola asuh yang baik akan menunjukkan cara berpikir yang baik pula, untuk menentukan arah dan menyeleksi perbuatan apa yang harus dikerjakan untuk menumbuhkan keinginan dan semangatnya dalam menyelesaikan skripsi, sehingga individu akan memiliki ciri tekun dan ulet dalam menghadapi segala tantangan yang akan mereka temui dalam menyelesaikan skripsi. 
Merujuk pada pembahasan diatas maka dapat disimpulkan bahwa masing-masing pola asuh orang tua yang ada akan memberikan pengaruh yang berbeda terhadap pembentukan kepribadian dan perilaku anak, sebab orang tua merupakan lingkungan terdekat yang selalu mengitari anak sekaligus menjadi figur dan idola mereka. Model perilaku orang tua secara langsung maupun tidak langsung akan dipelajari dan ditiru oleh anak seperti mengenai bagaimana orang tua bersikap, bertutur kata, mengekspresikan harapan, tuntutan dan kritikan satu sama lain, menanggapi, dan memecahkan masalah, mengungkapkan perasaan dan emosinya serta orientasinya untuk sukses.

Di dalam teori yang dicetuskan oleh Abraham Maslow (1970) yang disebut hierarki kebutuhan telah ditunjukan bahwa orang tua berperan penting untuk memenuhi tahapan kebutuhan dasar anak sebagai manusia yakni dimulai dari kebutuhan fisiologis, rasa aman, cinta dan kasih, dan aktualisasi diri. Hal ini menunjukan bahwa tanggung jawab yang dipikul orang tua memerlukan pemikiran dan perhatian yang besar dan segala hal yang ditanamkan orang tua dalam pola pengasuhannya, hal tersebut meninggalkan dasar yang paling dalam bagi pendidikan anak. Sehingga jika mahasiswa mendapatkan perlakuan (pola asuh) yang baik dari orang tua maka semakin baik pula motivasinya dalam menyelesaikan skripsi karena sikap mahasiswa terhadap akademik akan dipengaruhi oleh sikap orang tua mereka.

Pada penelitian ini menunjukkan hasil bahwa efikasi diri memiliki pengaruh terhadap motivasi dalam menyelesaikan skripsi, hal ini ditunjukkan dengan nilai t hitungnya 18,743 dengan signifikansi $0,000<0,05$. Nilai koefisien regresi efikasi diri menunjukkan nilai arah positif dengan motivasi dalam menyelesaikan skripsi yang dapat diartikan bahwa efikasi diri berpengaruh secara signifikan dan positif terhadap motivasi dalam menyelesaikan skripsi pada mahasiswa akhir Universitas Negeri Semarang tahun angkatan 2016, sehingga hipotesis kedua pada penelitian ini diterima.

Hasil ini sejalan dengan hasil penelitian yang dilakukan oleh Kusumawati (2018) menyatakan bahwa efikasi diri memberikan pengaruh terhadap motivasi berprestasi siswa dengan koefisien determinasi sebesar $49,2 \%$. Selain itu penelitian yang dilakukan oleh Amir (2016) juga menyatakan bahwa ada pengaruh signifikan dari aspek efikasi diri terhadap motivasi mahasiswa dengan koefisien determinasi sebesar 33,83\%. Hal ini menunjukkan bahwa efikasi diri yang dimiliki mahasiswa selalu berhubungan sangat erat dan akan sangat mempengaruhi motivasi yang dimilikinya.

Pada hasil analisis statistik deskriptif, variabel efikasi diri termasuk dalam kategori sedang. Ukuran efikasi diri pada mahasiswa akan mencerminkan pengaruh efikasi diri dalam menumbuhkan motivasi mahasiswa untuk menyelesaikan skripsi, karena efikasi diri dapat menentukan usaha dan ketekunan mahasiswa terutama dalam menghadapi hambatan dan pengalaman yang kurang menyenangkan selama menyelesaikan skripsi.

Hal ini sejalan dengan teori Bandura dalam Pajares (1996) mengenai efikasi diri, bahwa efikasi diri ini memiliki peran dalam mempengaruhi perilaku individu melalui beberapa cara yakni mempengaruhi pilihan yang diambil individu dan tindakan yang mereka kejar. Hal ini didukung oleh Retno Wulansari dalam Lestari (2014) menyatakan bahwa efikasi diri (self efficacy) berpengaruh terhadap : (1) pilihan perilaku, (2) pilihan karir, (3) kuantitas usaha dan keinginan bertahan pada suatu tugas, dan (4) kualitas usaha.

Berdasarkan pembahasan diatas dapat disimpulkan bahwa dengan efikasi diri yang dimiliki, individu akan mampu memilih atau menetapkan tindakan dan karier apa yang akan dilakukan untuk mencapai keinginan atau tujuannya. Usaha atau motivasi individu diukur sesuai tingkat efikasi dirinya seperti, mahasiswa akan mencoba dan berusaha lebih keras dalam menyelesaikan skripsi dimana efikasi diri mereka lebih tinggi daripada mereka yang memiliki efikasi diri rendah. Sehingga mahasiswa dengan efikasi diri yang tinggi ketika memasuki situasi penuh tekanan dengan percaya diri dan keyakinannya akan mampu bangkit dan bertahan menahan reaksi stress.

Ini berarti efikasi diri menentukan individu dalam memilih perilaku yang tepat, memiliki motivasi yang tinggi dalam berusaha, mampu bertahan ketika menghadapi masalah, memiliki pola pemikiran fasilitatif, serta lebih tahan terhadap stres. Sehingga, apabila mahasiswa memiliki efikasi diri yang tinggi, maka semakin tinggi pula motivasinya dalam menyelesaikan skripsi, 
karena mahasiswa yang memiliki efikasi diri yang tinggi dapat menumbuhkan dan menjaga keinginan serta semangatnya dalam menyelesaikan skripsi.

Berdasarkan penelitian yang telah dilakukan pada mahasiswa akhir Universitas Negeri Semarang tahun angkatan 2016 menunjukkan hasil bahwa pola asuh orang tua dan efikasi diri memiliki pengaruh secara simultan (bersama-sama) terhadap motivasi dalam menyelesaikan skripsi, hal ini ditunjukkan dengan nilai $F$ hitungnya 243,906 dengan signifikansi $0,000<0,05$. Nilai koefisien determinasi bernilai positif menunjukkan pengaruh pola asuh orang tua dan efikasi diri terhadap motivasi dalam menyelesaikan skripsi adalah positif. Hal tersebut berarti H3 yang berbunyi pola asuh orang tua dan efikasi diri berpengaruh positif terhadap motivasi dalam menyelesaikan skripsi dinyatakan diterima.

Hasil uji analisis koefisien determinasi (R Square) menunjukan angka sebesar 0,569 atau sama dengan $56,9 \%$. Sehingga dapat disimpulkan bahwa variabel Pola asuh dan Efikasi diri berpengaruh secara simultan terhadap variabel motivasi dalam menyelesaikan skripsi sebesar $56,9 \%$. Sedangkan sisanya $43,1 \%$ dipengaruhi oleh variabel lain di luar persamaan regresi ini atau di luar variabel yang diteliti. Oleh karena itu, dapat disimpulkan bahwa motivasi dalam menyelesaikan skripsi tidak akan diperoleh secara maksimal apabila pola asuh dan efikasi pada diri mahasiswa tidak maksimal pula.

Terdapat beberapa hal yang terjadi dan menjadi keterbatasan dalam penelitian ini, yakni responden yang tidak dapat ditemui secara langsung. Ketika melaksanakan penelitian ada dimasa peralihan situasi dari kebiasaan normal menuju pembiasaan diri untuk menghadapi pandemi covid-19 sehingga banyak sekali perubahan situasi dari berbagai sektor. Salah satu cara agar penelitian dapat berjalan dengan menyesuaikan protokol kesehatan yang diterapkan oleh pemerintah yakni pemanfaatan google form untuk penyebaran instrumen kepada mahasiswa, selain itu kuesioner menjadi salah satu sumber data pada penelitian ini, dimana kuesioner merupakan kumpulan pernyataan yang belum tentu menggambarkan kebenaran diri responden yag sebenarnya, dan jenis penelitian ini adalah penelitian kuantitatif dimana informasi yang disajikan kurang medalam.

\section{Simpulan}

Terdapat pengaruh yang positif dan signifikan pola asuh orang tua terhadap motivasi dalam menyelesaikan skripsi pada mahasiswa tingkat akhir Universitas Negeri Semarang tahun angkatan 2016. Terdapat pengaruh yang positif dan signifikan efikasi diri terhadap motivasi dalam menyelesaikan skripsi pada mahasiswa tingkat akhir Universitas Negeri Semarang tahun angkatan 2016. Terdapat pengaruh yang positif dan signifikan pola asuh orang tua dan efikasi diri terhadap motivasi dalam menyelesaikan skripsi pada mahasiswa tingkat akhir Universitas Negeri Semarang tahun angkatan 2016, ini memberikan arti bahwa motivasi dalam menyelesaikan skripsi tidak akan diperoleh secara maksimal apabila pola asuh dan efikasi pada diri mahasiswa tidak maksimal pula.

\section{Ucapan Terima Kasih}

Terimakasih kami ucapkan kepada pihak kampus yang telah mengizinkan penelitian ini berjalan, terimakasih kepada dosen pembimbing dan teman-teman seperjuangan dijurusan Bimbingan Konseling angkatan 2016, serta terimakasih yang sebesar-besarnya kepada seluruh rekan mahasiswa Universitas Negeri Semarang angkatan 2016 yang telah bersedia menjadi responden dalam penelitian ini. 


\section{Daftar Rujukan}

Amir, Hermansyah. 2016. Korelasi Pengaruh Faktor Efikasi Diri Dan Manajemen Diri Terhadap Motivasi Berprestasi Pada Mahasiswa Pendidikan Kimia Universitas Bengkulu. Manajer Pendidikan.

Arifah, Nur. 2016. Panduan Mudah Menyusun Skripsi, Tesis Dan Disertasi Lengkap Dengan Teknik Jitu Menyusun Proposal Agar Segera Disetujui. Yogyakarta: Araska.

Cervone, Daniel dan Pervin, Lawrence A. 2012. Kepribadian: Teori Dan Penelitian 2. 10th ed. edited by Terj. Aliya Tusyani; et. al. Jakarta: Salemba Humanika.

Dena Laksmi, Putu Putri, Ni Wayan Suniasih, and Komang Ngurah Wiyasa. 2018. Pengaruh Pola Asuh Orang Tua Terhadap Efikasi Diri Siswa Kelas V SD. Mimbar IImu.

Fitriyanti, E., \& Bilqis, F. (2020a). Penguasaan konten analisis doodle art meningkatkan self efficacy mahasiswa UPBK Unindra dalam memberikan layanan konseling. TERAPUTIK: Jurnal Bimbingan Dan Konseling, 4(2), 175-182.

Fitriyanti, E., \& Bilqis, F. (2020b). PKM layanan PKO analisis doodle art sebagai media self efficacy mahasiswa Prodi matematika \& UPBK Unindra. TERAPUTIK: Jurnal Bimbingan Dan Konseling, 4(2), 285-292.

Kusumawati, Erlin Dwi. 2018. Pengaruh Adversity Quotient, Regulasi Diri Dan Efikasi Diri Terhadap Motivasi Berprestasi Siswa KKO SMP Negeri 13 Yogyakarta. Jurnal Pendidikan Agama Islam.

Lestari, Ika Putri Kanthi. 2014. Upaya Meningkatkan Self Efficacy Rendah Terhadap Pemilihan Karir Dengan Konseling Behaviour Teknik Modeling Simbolik Pada Siswa Kelas VIII E Di SMPN N 6 Batang.Universitas Negeri Semarang.

Maulana, Arief. 2012. Cara Instan Menyusun Skripsi. Cetakan 1. edited by Latief. Jakarta Timur: New Agogos.

Pajares, Frank. 1996. Self-Efficacy Beliefs in Academic Settings." Review of Educational Research.

Zulkarnain, Iskandar. 2010. Siasat Dan Langkah Sukses Menyusun Skripsi. 2nd ed. Yogyakarta: Pinus Book Publisher.

\section{Competing interests:}

The authors declare that they have no significant competing financial, professional or personal interests that might have influenced the performance or presentation of the work described in this manuscript. 